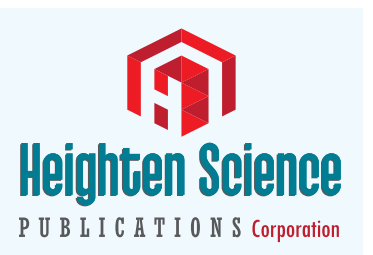

ISSN

2640-2890
*Address for Correspondence: Funda Atalay, University of Health Sciences, Dr. AY Ankara Oncology Education and Research Hospital, Department of Gynecologic Oncology, Ankara, Turkey, Tel: 905325643555 ;

Email: atalayfundak@yahoo.com

Submitted: 06 December 2018

Approved: 18 December 2018

Published: 19 December 2018

Copyright: @ 2018 Saglam H, et al. This is an open access article distributed under the Creative Commons Attribution License, which permits unrestricted use, distribution, and reproduction in any medium, provided the original work is properly cited

Keywords: Mature cystic teratoma; Ovary; Tumor markers: Radiologic imaging

Check for updates
Research Article

\section{The predictive value of the preoperative diagnostic tests in mature cystic teratomas of the ovary}

\author{
Hanife Saglam ${ }^{1}$, Funda Atalay ${ }^{1 *}$, Ayse Filiz Avsar ${ }^{2}$ and Hüseyin \\ Levent Keskin ${ }^{3}$ \\ 'University of Health Sciences, Dr. AY Ankara Oncology Education and Research Hospital, \\ Department of Gynecologic Oncology, Ankara, Turkey \\ ${ }^{2}$ Ankara Yıldırım Beyazıt University, School of Medicine, Department of Obstetrics and Gynecology, \\ Ankara, Turkey \\ ${ }^{3}$ University of Health Sciences, Zekai Tahir Burak Women's Health Education and Research \\ Hospital, Department of Obstetrics and Gynecology, Ankara, Turkey
}

\section{Abstract}

Aim: The aim of this study was to determine the sensitivity of the tumor markers and diagnostic methods used in the preoperative period for dermoid cysts, the most common benign neoplasm of the ovary.

Material and Methods: 136 patients who were operated for any reason and reported as ovarian dermoid cyst in the Department of Obstetrics and Gynecology, Ankara Atatürk Training and Research Hospital between January 2004 and September 2005 were included in the study. The medical records of the cases were obtained retrospectively from Ankara-Atatürk Training and Research Hospital, HIS, archive files and patient numbers where necessary.

Results: In the preoperative period, 119 patients underwent ultrasonographic examination, 33 underwent Computed Tomography, and 17 underwent Magnetic Resonance Imaging. 10 of the cases only underwent CT, while 3 of the cases underwent only MRI 22 of them underwent both USG and CT, USG and MRI were performed on 13 cases and only 1 case underwent all three of the imaging methods. Tumor markers were CEA, CA 125, CA 19-9, CA 15-3 and AFP.

Conclusion: The reviews of ultrasonography and / or computed tomography and / or magnetic resonance imaging $(n=132)$ revealed that 103 of the cases were put into operation and the sensitivity of the preoperative screening methods were calculated to be $75.5 \%$. The sensitivity of the tumor marker CA $19-9$ was calculated to be $31 \%$.

\section{Introduction}

Mature cystic teratomas (MCT) constitute $10-25 \%$ of all ovarian neoplasia and $60 \%$ of all benign ovarian neoplasms [1-3]. MCT forms more than 95\% percent of all over teratomas and is always benign [4]. Teratomas consist of a single germ cell and therefore may contain any or all of the three germ layers (ectoderm, mesoderm or endoderm) [5]. These layers typically form tissues with different and irregular structures in the ovary [5,6]. More than $95 \%$ of all ovarian teratomas are formed by MCT and is always benign [4]. It is the most common ovarian germ cell tumor in reproductive age women [7]. Approximately $8-17 \%$ of the cases were bilateral [1,3,8-10]. Malign transformation can be seen in $0.5 . \%$ to $8 \%$ of the cases (especially in postmenopausal women). Since these cysts are mostly covered with squamous epithelium, $80 \%$ of malignant cases are composed of squamous cell carcinoma [11].

The characteristic macroscopic appearance of MCT is the multicystic mass with hair, 
teeth, and / or sebaceous / thick, sticky, and usually mixed with malodorous material. There is a solid protrusion (Rokitansky nodule) between the teratoma and normal ovarian tissue $[12,13]$. MCT may microscopically contain endodermal, mesodermal and ectodermal mature tissues, but generally ectodermal elements outbalance the others [6,14].

These neoplasms, which are always benign, are usually asymptomatic, but may present with abdominal distension, abdominal mass, constipation, nausea, vomiting, or signs of infection, depending on the size of the masses. The most important complications that may develop from MCT are rupture, torsion and malignancy risk. Therefore, surgical removal is recommended [15-17]. Surgical excision provides definitive diagnosis in most women with mature cystic teratomas, eliminating symptoms and preventing complications such as torsion, rupture, and malignant degeneration. As with other ovarian cysts, surgery may be by laparoscopic approach or laparotomy, and cystectomy or oophorectomy may be performed [18].

The basic imaging tool for preoperative examination of MCT is ultrasonography (USG). The density of these tumors varies from full cyst to full solitary and, in particular, unlike many other ovarian tumors of the MCT, these tumors has many sonographic characteristic features such as oil-liquid or hair-liquid levels, bristle density, Rokitansky overhang, Iceberg tip, dot-dash, floating balls sign $[6,19,20]$. The superiority of magnetic resonance Imaging (MRI) to other imaging modalities used in pelvis include direct multiplanar examination ability, high soft tissue contrast, the ability to differentiate the veins without using contrast media and the safe use of them in pregnant women. Characteristic/typical MRI finding is the fatty tissue seen in about $95 \%$ of cases. Other findings are liquid-liquid levels, low signal intensity calcification (usually tooth tissue) and Rokitansky nodules, chemical transition artifact, oil-liquid level, palm tree-like protrusion, floating ball sign, intratumoral keratinoid material [21-25]. Standard T1 and T2 imaging sequences support the diagnosis of teratoma, but T1-weighted out-of-phase or chemically selective fatty tissue imprinted images increase diagnostic confidence. Diagnostic accuracy of these techniques has been reported up to 96\%. [22]. Out-ofphase imaging may be particularly advantageous for lesions containing small amounts of fat [23]. Computed tomography (CT) has excellent sensitivity (93-98\%) due to the determination of fat in the diagnosis of MCT [23]. Computed tomography includes a mass in fat density with or without fat-fluid level. The high density Rokitansky node consisting of hair and other components can swim in the middle of the mass and calcification is frequently present [26]. The sign of floating balls is a striking and rare finding of MCT and consists of several small spherical structures within the cyst [27].

Tumor markers may show a slight increase in MCT [28]. CA 125, CA 19-9, carcinoembryonic antigen (CEA) are markers that can increase in MCT $[29,30]$.

The aim of this study is to determine the predictive values of the tests performed for diagnosis in the preoperative period and to reach a fast and accurate diagnosis with low cost of this disease, which is frequently encountered in the reproductive period and which has various complications including loss of fertility if not treated.

\section{Material and Method}

Between the dates of January 2004 and September 2015, in Ankara Atatürk Training and Research Hospital, Department of Obstetrics and Gynecology a total of 136 patients were included who got operated for whatever reason and reported as ovary mature cystic teratoma. The medical records of the patients were retrospectively reviewed and the patient information (archive files and patient phone numbers) was obtained from hospital recording system. Where necessary. The records of the patients were fully screened; age, gravida, parity, menopause, preoperative imaging methods and histopathological diagnosis were recorded. 
In the preoperative period, 119 patients were diagnosed with USG, 33 patients with CT, and 17 patients with MRI. Only CT was performed on 10 cases, on 3 cases only MRI was performed, CT was performed on 22 patients with USG, MRI was performed with USG on 13 patients, and all three imaging methods were performed on one patient.CT and MRI were done as additional radiological examination when 33 (24.3\%) of the patients couldn't be pre-diagnosed with USG or their tumor markers were high (especially CA125 ) or when there was suspicion of malignancy or the result of USG was no good as a result of obesity. The tumor markers AFP, CA-125, CA 15-3, CA 19-9 and CEA were examined. In the USG, the diameter of the tumor, the side of the tumor and whether it is unilateral or bilateral, the presence of septation without consideration of septa thickness, the presence of solid-cystic separation, fat density, presence of acoustic shadowing, calcification and hyper-echogenicity were recorded. The diameter of the tumor, the presence of fat-bone density and the possibility of "dermoid" prediction evaluated by computed tomography. The diameter of the tumor, the presence of bone density, and the possibility of the "dermoid" were analyzed in the cases that underwent MRI.

Cases who did not pre-diagnosed with ovarian cyst were recorded as incidental. Patient data were analyzed in SPSS 17.0 Statistical Program. Descriptive data were shown as number (n),\% (\%), mean \pm standard deviation (SD), minimum and maximum. Mean values of groups and comparison between groups were done by One-way ANOVA method while evaluating the tumor diameters.

\section{Results}

The mean age of the cases was $38.8 \pm 13.2$ (18-75). The number of cases under 20 years of age was 8 (5.9\%). Of the 119 cases who underwent ultrasonography, 80 were diagnosed as MCT preoperative sensitivity of USG was calculated as $67.2 \%$. In CT 26 (78.8\%) of the patients were diagnosed as " MCT" while 3 (9.4\%) cases were defined as cystic lesions and $2(6.3 \%)$ cases were interpreted as necrotic masses. One (3.1\%) patient diagnosed as malignant $1(3.1 \%)$ before surgery, was sigmoid colon mass. 3 (17.7\%) of the cases evaluated with MRI showed bone density. While 12 (70.6\%) of the cases were diagnosed as MCT, 5 (29.4\%) cases were defined as cystic structure. As a result of USG and / or CT and / or MRI ( $=132), 103$ patients were operated with the pre-diagnosis of MCT. Preoperative evaluation sensitivity of the imaging methods was calculated to be $75.7 \%$. 26 of the 33 patients evaluated with CT had a preoperative diagnosis of MCT and sensitivity was 78.8\%. 12 of the 17 patients with MRI imaging supported the preoperative diagnosis of MCT, with a sensitivity of $70.6 \%$. Sensitivity of tumor markers CA 125 , CA $15-3$ and AFP were respectively calculated to be $16 \%$, $10.7 \%$ and $6 \%$ while CA $19-9$ and CEA were $31 \%$ and $20.4 \%$

Of the 136 patients diagnosed with MCT as a result of histopathological evaluation, 103 had the correct diagnosis of MCT preoperatively, two of which were associated with pregnancy. In 20 cases, the pre-diagnosis was defined as ovarian cyst / adnexial mass and 3 cases presented with acute abdomen and operated with pre-diagnosis of ovarian torsion.In 2 cases, the operation was performed with the preliminary diagnosis of tubaovaryan abscess and ovarian malignancy, but MCT was found in the postoperative diagnosis.In the remaining 8 cases, the indications for surgery were caesarean section $(n=3)$, acute abdomen (appendectomy, $n=1$, ectopic pregnancy, $n$ $=2)$, endometrial cancer $(n=1)$, hysterectomy due to myoma $(n=1)$ and preoperative period. While MCT was not detected by imaging methods, it was reported as mature cystic teratoma as a result of pathological examination of ovarian cyst which was detected intraoperatively.

Histopathological examination results of one patient $(0.7 \%)$ were reported as immature teratoma, one case $(0.7 \%)$ as malignant transformation and $2(1.5 \%)$ cases as struma ovarii. Tumor markers CA 19-9 and AFP levels were found in the cases reported above normal values (CA 19-9 $=114 \mathrm{kU} / \mathrm{L}, \mathrm{AFP}=70.08 \mathrm{ng} / \mathrm{ml}$ ) in immature teratoma. 
In our study, 5 out of 7 cases who were only examined with USG and were reported as bilateral had been diagnosed with MCT in bilateral ovaries while 2 out of 7 didn't show any signs MCT or any other ovarian pathology. However, 3 of the cases with unilateral ovarian cysts had bilateral MCT in the ovaries tables 1-4.

\begin{tabular}{|c|c|c|c|}
\hline \multicolumn{2}{|c|}{ Ultrasonographic feature } & $n$ & $\%$ \\
\hline \multicolumn{2}{|c|}{ Presence of septation } & 25 & 21 \\
\hline \multicolumn{2}{|c|}{ Solid structure } & 17 & 14.28 \\
\hline \multicolumn{2}{|c|}{ Cystic structure } & 26 & 21.84 \\
\hline \multicolumn{2}{|c|}{ Solid-cystic structure } & 70 & 58.82 \\
\hline \multirow{4}{*}{ 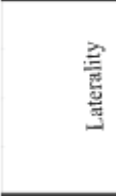 } & Right & 58 & 48.7 \\
\hline & Left & 42 & 35.3 \\
\hline & Bilateral & 7 & 5.9 \\
\hline & Unspecified & 12 & 10.1 \\
\hline \multicolumn{2}{|c|}{ Calcification } & 22 & 18.5 \\
\hline \multicolumn{2}{|c|}{ Acoustic shadowing } & 11 & 9.2 \\
\hline \multicolumn{2}{|c|}{ Hyperechogenicity } & 55 & 46.2 \\
\hline \multicolumn{2}{|l|}{ Fat density } & 13 & 10.9 \\
\hline
\end{tabular}

\begin{tabular}{l|c|c|} 
Tomographic feature & $\mathbf{n}$ & $\%$ \\
\hline Cystic structure & 10 & 31.3 \\
\hline Solid stucture & 9 & 28.1 \\
\hline Solid-cystic structure & 11 & 34.4 \\
\hline Solid-cystic structure not specified & 2 & 6.26 \\
\hline Fat density & 24 & 75 \\
\hline Bone density & 15 & 46.9
\end{tabular}

Table 2: Tomographic features of cases.

\begin{tabular}{|c|c|c|c|c|}
\hline $\begin{array}{l}\text { Tumor } \\
\text { marker }\end{array}$ & Mean \pm SD & Median & Least value & Most value \\
\hline $\begin{array}{|ll|}\text { AFP } & (\mathrm{ng} / \mathrm{ml}) \\
\mathrm{n}=62 & \\
\end{array}$ & $4.0 \pm 9.3$ & 1.8 & 0 & 70 \\
\hline $\begin{array}{|ll|}\text { CEA } & (\mathrm{ng} / \mathrm{ml}) \\
\mathrm{n}=93 & \\
\end{array}$ & $1.8 \pm 1.5$ & 1.4 & 0 & 8.6 \\
\hline \begin{tabular}{|l|l|} 
CA & 125 \\
$\mathrm{n}=119$
\end{tabular} & $22.2 \pm 59.2$ & 15.1 & 2.1 & 571 \\
\hline $\begin{array}{|lc|}\mathrm{CA} & 19-9 \\
(\mathrm{KU} / \mathrm{L}) \mathrm{n}=110\end{array}$ & $\begin{array}{ll}65.6 & \pm \\
244.4 & \end{array}$ & 15.4 & 0.6 & 2408 \\
\hline
\end{tabular}

Table 3: Findings on tumor markers.

\begin{tabular}{l|l|l|l|l} 
& $\begin{array}{c}\text { Between } \\
0-5 \mathrm{~cm}\end{array}$ & $\begin{array}{c}\text { Between } \\
\text { 6-10 cm }\end{array}$ & $\begin{array}{c}11 \mathrm{~cm} \text { and } \\
\text { above }\end{array}$ & $\mathbf{p}$ \\
\hline CA 125 & $15.2 \pm 9.1$ & $36.4 \pm 84.1$ & $30 \pm 24.1$ & 0.202 \\
\hline CEA & $1.1 \pm 1.2$ & $1.8 \pm 1.7$ & $1.8 \pm 1.2$ & 0.993 \\
\hline CA 19-9 & $24.3 \pm 30.9$ & $106.5 \pm 353.7$ & $46 \pm 57$ & 0.264 \\
\hline CA 15-3 & $15.7 \pm 8.0$ & $15.4 \pm 7.2$ & $19.9 \pm 17.4$ & 0.253 \\
\hline AFP & $3.2 \pm 4.3$ & $2.8 \pm 3.6$ & $9.9 \pm 22.6$ & 0.119
\end{tabular}

Table 4: Relationship between tumor markers and macroscopic diameters of tumors. 


\section{Discussion}

Although these neoplasms, which are frequently seen in the reproductive period, are usually asymptomatic, it is important to diagnose and treat at an early stage because they have various complications, including loss of fertility, if not treated. In the study conducted by Genç et al., 33 patients were examined and 21 patients $(63.6 \%)$ were correctly diagnosed as MCT by preoperative ultrasonography. These results are similar to our study [31]. Mais et al. determined that sensitivity and specificity were $58 \%$ and $99 \%$, respectively according to findings in USG such as, dens echogenic nodules, focal or diffuse echogenic foci, and multiple echogenic lines formed by hairs in MCT [32].

In our study, the ultrasonographic examination of the lesions, solid, cystic, solidcystic, fat density, calcification, acoustic shadowing, and hyper-echogenicity patterns, preoperative mature cystic teratoma was diagnosed in 80 of 119 cases. Sensitivity of USG was found to be $67.2 \%$. de Kroon et al. found sensitivity to $80 \%$ and specificity to $89 \%$ in studies involving 99 dermoid cysts [33].

In a study conducted by Tekin et al., of 40 patients with MCT diagnosed as ultrasonographic preliminary diagnoses from 245 patients who were operated with the diagnosis of adnexal mass, the compatibility between the initial diagnosis and the true diagnosis was found to be statistically significant. The sensitivity of ultrasonography (81.8\%), specificity (93.1\%), PPV (67.5\%) and NPV (96.7\%) were also found to be high [34]. In the published studies it is stated that acoustic shadowing, focal or diffuse hyperechoic foci, hyperechogenic ridge formed by hair can be seen at the rates of $90 \%, 60 \%$ and $60 \%$ again respectively [24]. Tekin et al. reported in their study that even though hyperechoic solid component was detected in $89,5 \%$ cases and mixed echogenicity due to hyperechogenic fine lines in $77,4 \%$ cases, acoustic shadowing was only detected in $12,5 \%$ of the cases [34]. In the same study, it was found out that 13 of 40 patients who were thought to have MCT ultrasonographically, were misdiagnosed and it was showened that the reason of diagnosis of misdiagnosis is to take the criteria of hyperechogenic lining and hyperechogenic solid structure in the pattern recognition method as a diagnostic criteria [34].

Computed tomography has a high sensitivity for detecting MCT. Measurement of fat density is difficult in cases where the fat in the lesion is low. Other than the fat density, palm tree-like protrusion and fat-liquid levels are other specific findings that can be seen on CT. On CT, the fat-liquid level can be seen at 10\% [23]. In the study of Saba et al., CT revealed typical features of MCT to be, fat density $93 \%$ teeth and calcifications $56 \%$ Rokitansky nodule and $81 \%$ hair density $65 \%$ fat-liquid levels $12 \%$ respectively [35-42]. Guerriero et al. evaluated 83 adnexal masses who persisted after 3 months of the 161 cases they examined. They were able to diagnose MCT with $100 \%$ sensitivity and specificity in 14 cysts and obtained higher sensitivity when compared with MRI [43]. Similarly, Buy et al. compared the preoperative CT and MRI findings of lesions in 25 cases with histopathological results reported as MCT Rokitansky protrusion, fat and calcified tissue characterization were evaluated in CT and MRI and they found the sensitivity of CT to be $98 \%$ and MRI was $88 \%$ [44]. In our study, considering the features reported with $\mathrm{CT}$, while the cystic structure was evaluated as $31.3 \%$, solid structure as $28.1 \%$, solid-cystic structure as $34.4 \%$, fat density as $75 \%$ and bone density as $46.9 \%$; bone density was determined in $3(17.7 \%)$ of the cases evaluated by MRI and 12 (70.6\%) of the cases were diagnosed as "MCT" without any descriptive characteristic and $5(29.4 \%)$ cases were defined only as cystic structure. Saba et al. in their review of the MRI, fat, fat-liquid, hair densities, palm tree protrusions and protrusions in the appearance of MCT are emphasized as typical features [15-17,45-49].

When we look at the tumor markers in our study, CA 125 sensitivity, which is essentially important in the diagnosis of epithelial ovarian neoplasms, was found to be 
$16 \%$ in the diagnosis of MCT, a germ cell ovarian tumor. Kawai, Kikkawa, and Mikuni have shown that CA-125 values in patients with MCTs have increased by $23.7 \%, 28 \%$ and $12.7 \%$, respectively, which are similar to our data [50-52].

In our study, the sensitivity of CA 15-3 in the diagnosis of MCTwas found to be $10.7 \%$. AFP sensitivity was calculated as $6 \%$. In a study by Konishi et al., CEA levels increased to $30 \%$ of cases diagnosed with MCT. Whereas Kawai et al., couldn't find any significant rise in CEA levels with cases who have MCT [51-53]. In our study, CEA sensitivity was calculated as $20.4 \%$. In a study of Var et al. on 160 patients, CA 19-9 was found in $37.6 \%$ of the cases, CA 125 was present in 19.3\%, CEA in $9.4 \%$, CA 15-3 in $4 \%$ and AFP levels were high in $0,9 \%$ of the aforementioned cases. In the study where they detected that CA 19-9 is a more accurate marker in ovarian MCT, they discovered that the most important determinant of CA 19-9 level was the diameter of tumor [54]. In our study, CA 19-9 was higher in MCT than the other tumor markers and in 34 of the 110 cases, it was found to be higher than normal values and its sensitivity was calculated as $31 \%$.

Studies have focused on the correlation of tumor diameter and height of tumor markers. Mikuni and Dede did not find a significant relationship between CA 19-9 level and tumor diameter, but they detected a significant relationship between CA19-9 level and tumor diameter.In the study of Var et al. while it is observed normally in cases with tumors whose diameter is below $4 \mathrm{~cm}, \mathrm{CA}$ 19-9 levels start to rise in tumors with diameter between 4-10 $\mathrm{cm}$ and in tumors which have diameters over $10 \mathrm{~cm}$ CA 19-9 levels are still on the rise as well as CA 125 and CEA [52,54,55].

We did not find a relationship between tumor size and height of tumor markers.

\section{Conclusion}

MCT is the most common germ cell tumor of the ovary, which constitutes approximately $10-25 \%$ of all ovarian neoplasms and $60 \%$ of all benign ovarian neoplasms. Although MCT is usually asymptomatic, symptoms in symptomatic cases may present us with symptoms such as abdominal distension, abdominal mass, constipation, nausea, vomiting, infection, torsion or rupture, depending on the size of the masses. The fact that the Rokitansky bulge was not reported at all in our CT and MRI reports and that the characteristics of the mass were not specified were the limitations of our study within the framework of standardization. One of the limitations of our study was that when the imaging methods were reported, the definitions were in the form of general expressions. Although it is called "MCT" by the radiologist, it is necessary to have radiologists working on this subject and the procedure should be done by the same radiologist and this situation has not been achieved in our study.

As a result, sonography is the primary imaging tool used to determine MCT. It is seen that we need more descriptive radiology reports to achieve correct pre-operative diagnosis and standardization by supporting with CT and / or MRI. Preoperative tumor markers appear to have no place in the diagnosis and validation of MCT. The thesis that tumor markers increase with increasing tumor size needs to be supported by studies.

\section{References}

1. Katsube Y, Berg JW, Silverberg SG. Epidemiologic pathology of ovarian tumors: a histopathologic review of primary ovarian neoplasms diagnosed in the Denver Standard Metropolitan Statistical Area, 1 July-31 December 1969 and 1 July-31 December 1979. Int J Gynecol Pathol. 1982; 1: 3-16. Ref.: https://goo.gl/9VS41X

2. Koonings PP, Campbell K, Mishell DR Jr, Grimes DA. Relative frequency of primary ovarian neoplasms: a 10-year review. Obstet Gynecol. 1989; 74: 921-926. Ref.: https://goo.gl/FySxpo

3. Peterson WF, Prevost EC, Edmunds FT, Hundley JM Jr, Morris FK. Benign cystic teratomas of the ovary; a clinico-statistical study of 1,007 cases with a review of the literature. Am J Obstet Gynecol. 1955; 70: 368-382. Ref.: https://goo.gl/d9MJpd 
4. Ayhan A, Bukulmez O, Genc C, Karamursel BS, Ayhan A. Mature cystic teratomas of the ovary: case series from one institution over 34 years. Eur J Obstet Gynecol Reprod Biol. 2000; 88: 153-157. Ref.: https://goo.gl/vF4rN8

5. Pantoja E, Rodriguez-Ibanez I, Axtmayer RW, Noy MA, Pelegrina I. Complications of dermoid tumors of the ovary. Obstet Gynecol. 1975; 45: 89-94. Ref.: https://goo.gl/W4iN2k

6. Hoffman BL. Schorge JO, Schaffer JI, Halvorson LM, Bradshaw KD, et al. eds. Wiiliams Gynecology. Texas: Mc Graw Hill. 2012; 267. Ref.: https://goo.gl/M4dgvf

7. Yoshioka T, Tanaka T. Immunohistochemical and molecular studies on malignant transformation in mature cystic teratoma of the ovary. J Obstet Gynaecol Res. 1998; 24: 83-90. Ref.: h ttps://goo.gl/AQJXtT

8. Caruso PA, Marsh MR, Minkowitz S, Karten G. An intense clinicopathologic study of 305 teratomas of the ovary. Cancer. 1971; 27: 343-348. Ref.: https://goo.gl/TY4E6A

9. Ozgur T, Atik E, Silfeler DB, Toprak S. Mature cystic teratomas in our serieswith review of the literature and retrospective analysis. Arch Gynecol Obstet. 2012; 285: 1099-1101. Ref.: https://goo.gl/9sVnp1

10. Bagolan P, Giorlandino C, Nahom A, Bilancioni E, Trucchi A, et al. The management of fetal ovarian cysts. J Pediatr Surg. 2002; 37: 25-30. Ref.: https://goo.gl/GhynQd

11. Chiang AJ, La V, Peng J, Yu KJ, Teng NN. Squamous cell carcinoma arising from mature cystic teratoma of the ovary. Int J Gynecol Cancer. 2011; 21: 466-474. Ref.: https://goo.gl/hbohPb

12. Comerci JT Jr, Licciardi F, Bergh PA, Gregori C, Breen JL. Mature cystic teratoma: a clinicopathologic evaluation of 517 cases and review of the literature. Obstet Gynecol. 1994; 84: 22-28. Ref.: https://goo.gl/eDC874

13. Breen JL, Maxson WS. Ovarian tumors in children and adolescents. Clin Obstet Gynecol. 1977; 20: 607-623. Ref.: https://goo.gl/Jie1x1

14. Giorlandino C1, Bilancioni E, Bagolan P, Muzii L, Rivosecchi M, et al. Antenatal ultrasonographic diagnosis and management of fetal ovarian cysts. Int J Gynaecol Obstet. 1994; 44: 27-31. Ref.: https://goo.gl/ejMv5T

15. Salman W, Singh M, Twaij Z. A case of papillary thyroid carcinoma in struma ovarii and review of the literature. Patholog Res Int. 2010; 2010: 352476. https://goo.gl/UJHLSx

16. Lal S, Singh A, Goel N. Acute gynaecological emergency caused by ruptured dermoid. JEMDS. 2014; 3: 5705-5710. Ref.: https://goo.gl/fEmrba

17. Artunc UB, Goker A, Pala HG, Ordu S. Abnormal elevated ca 19-9 in the dermoid cyst: a sign of the ovarian torsion? Case Rep Obstet Gynecol. 2013; 2013: 860505 Ref.: https://goo.gl/JnNTxM

18. Comerci JT Jr, Licciardi F, Bergh PA, Gregori C, Breen JL. Mature cystic teratoma: a clinicopathologic evaluation of 517 cases and review of the literature. Obstet Gynecol. 1994; 84: 22-28. Ref.: https://goo.gl/6SCsPM

19. Sahin H, Abdullazade S2, Sanci M. Mature cystic teratoma of the ovary: a cutting edge overview on imaging features. Insights Imaging. 2017: 8: 227-241. Ref.: https://goo.gl/LUn7ff

20. Patel MD, Feldstein VA, Lipson SD, Chen DC, Filly RA. Cystic teratoma of the ovary: diagnostic value of sonography. AJR Am J Roentgenol. 1998; 171: 1061-1065 Ref.: https://goo.gl/C1Ki8w

21. Dooms GC, Hricak H, Tscholakoff D. Adnexal structures: MR imaging. Radiology. 1986; 158: 639646. Ref.: https://goo.gl/Ax2kXj

22. Mitchell DG, Mintz MC, Spritzer CE, Gussman D, Arger PH, et al. Adnexal masses: MR imaging observations at 1.5 T, with US and CT correlation. Radiology. 1987; 162: 319-324. Ref.: https://goo.gl/RFYAxm

23. Saba L, Guerriero S, Sulcis R, Virgilio B, Melis G, et al. Mature and immature ovarian teratomas: CT, US and MR imaging characteristics. Eur J Radiol. 2009; 72: 454-463. Ref.: https://goo.gl/tp3VZG

24. Togashi K, Nishimura K, Itoh K, Fujisawal, Sago T, et al. Ovarian cystic teratomas: MR imaging Radiology. 1987; 162: 669-673. Ref.: https://goo.gl/kgcB16

25. Nakamaya T, Yoshimitsu K, Irie H, Aibe H, Tajima T, et al. Diffusion- weighted echo-planar MR imaging and ADC mapping in the differential diagnosis of ovarian cystic masses: usefulness of detecting keratinoid substances in mature cystic teratomas. J Magn Reson Imaging. 2005; 22: 271-278. Ref.: https://goo.gl/CWRi7M

26. Matsumoto F, Yoshioka H, Hamada T, Ishida O, Noda K. Struma ovarii: CT and MR findings. J Comput Assit Tomgr. 1990; Mr-Opr; 14: 310-312. Ref.: https://goo.gl/CDPsU4 
27. Mahomedy S, Bayat MR, Seedat M. Meat balls: a pathognomonic ultrasound and computed tomography finding in mature cystic teratoma. Australas Radiol. 2007; 51: B281-B283 Ref.: https://goo.gl/EXCEFB

28. Hackethal A, Brueggmann D, Bohlmann MK. Et al. Squamous-cell carcinoma in mature cystic teratoma of the ovary: systematic review and analysis of published data. Lancet Oncol. 2008; 9: 1173-1780. Ref.: https://goo.gl/bhdJNk

29. Yüksel MA, Abal> R, Aras Ö, Temel, Ünal F, Boran AB, Purisa S. Ovaryan Dermoid Kistlerde CA 19-9 Seviyesinin Deaerlendirilmesi. Türkiye Klinikleri Jinekoloji-Obstetrik Dergisi. 2011; 21: 190-194. Ref.: https://goo.gl/CAGWZy

30. Günay E, Kalender HS, Cengizođlu B, Turan C, Ünal O. Adneksiyal Kitlelerde Tümör "Marker"lar> ve Cerrahi Sonuçlar ’. Kartal eđitim Arafl. Hast. T’p Dergisi. 2002; 3: 179-181 Ref.: https://goo.gl/cWTAJB

31. Genç M, Şahin N, Karaarslan S. Mature Cystic Teratoma of the Ovary Clinical, Radiological and, Histopathologic Aspects. Journal of Clinical and Analytical Medicine. 2016; 370-374. Ref.: https://goo.gl/nCnCb8

32. Mais V, Guerriero S, Ajossa S, Angiolucci M, Paoletti AM, et al. Transvaginal ultrasonography in the diagnosis of cystic teratoma. Obstet Gynecol. 1995; 85: 48-52. Ref.: https://goo.gl/eYdBTg

33. de Kroon CD, van der Sandt HA, van Houwelingen JC, Jansen FW. Sonographic assesment of non-malignant ovarian cysts; does sonohistology exist? Hum Reprod. 2004; 19: 2138-2143. Ref.: https://goo.gl/nviKxF

34. Tekin YB, Altınbaş ŞK, Dede $S$, et al. The parameters affecting accuracy of ultrasonographic diagnosis in dermoid cysts. Dicle Medical Journal. 2014; 41: 64-70.

35. Andolf $\mathrm{E}$, Jorgensen $\mathrm{C}$. A prospective comparison of transabdominal and transvaginal ultrasound with surgical findings in gynecologic disease. J Ultrasound Med. 1990; 9: 71-75. Ref.: https://goo.gl/6U152N

36. Hata K, Hata T, Manabe A, Sugimura K, Kitao M. A critical evaluation of transvaginal Doppler studies, transvaginal sonography, magnetic resonance imaging, and CA 125 in detecting ovarian cancer Obstet Gynecol. 1992; 80: 922-926. Ref.: https://goo.gl/V96WPQ

37. Kurjak A, Predanic M, Kupesic-Urek S, Jukic S. Transvaginal color and pulsed Doppler assessment of adnexal tumor vascularity. Gynecol Oncol. 1993; 50: 3-9. Ref.: https://goo.gl/JzBDVz

38. Lerner JP, Timor-Tritsch IE, Federman A, Abramovich G. Transvaginal ultrasonographic characterization of ovarian masses with an improved, weighted scoring system. Am J Obstet Gynecol. 1994; 170: 81-85. Ref.: https://goo.gl/YXHJw3

39. Quinn SF, Erickson S, Black WC. Cystic ovarian teratomas: the sonographic appearance of the dermoid plug. Radiology. 1985; 155: 477-478. Ref.: https://goo.gl/92kK3R

40. Dodd GD, Budzik RF. Lipomatous tumors of the pelvis in women: spectrum of imaging findings. AJR Am J Roentgenol. 1990; 155: 317-322. https://goo.gl/QThLmR

41. Sheth S, Fishman EK, Buck JL, Hamper UM, Sanders RC. The variable sonographic appearances of ovarian teratomas: correlation with CT. AJR Am J Roentgenol. 1988; 151: 331-334. Ref.: https://goo.gl/fTNPZ8

42. Fridman AC, Pyatt RS, Hartmann DS, Downey EF, Olson WB. CT of benign cystic teratomas. AJR Am J Roentgenol. 1982; 138: 659-665. Ref.: https://goo.gl/7L8AR8

43. Guerriero S, Mallarini G, Ajossa S, Risalvato A, Satta R, et al. Transvaginal ultrasound and computer tomography combined with clinical parameters and CA-125 determinations in the differential diagnosis of persistent ovarian cysts in premenopausal women. Ultrasound Obstet Gynecol. 1997; 9: 339-334 Ref.: https://goo.gl/5MbPtf

44. Buy JN, Ghossain MA, Moss AA, Bazot M, Doucet M, et al. Cystic teratoma of the ovary: CT detection. Radiology. 1989; 171: 697-701. Ref.: https://goo.gl/iyRSXy

45. Laufer M, Goldstein D. Benign and malignant ovarian masses. In: Emans S; Laufer M Goldstein, D editors. Pediatric and Adolescent Gynecology. 5th ed. Philadelphia: Lippincott Williams and Wilkins; 2005. 706-710.

46. Zeyneloğlu HB, Öktem M, Eroğlu D, Kuşçu E. Matür kistik teratomlara laparoskopik yaklaşım: Başkent Üniversitesi deneyimi. J Turk Soc Obstet Gynecol. 2005; 2: 116-120. Ref.: https://goo.gl/kLKVkY

47. Leibman AJ, Kruse B, McSweeney MB. Transvaginal sonography: comparison with transabdominal sonography in the diagnosis of pelvic masses. Am J Roentgenol. 1988; 151: 89-92. Ref.: https://goo.gl/FjzmuN 
48. Guttman PH Jr: In search of the elusive benign cystic ovarian teratoma: application of the ultrasound "tip of the iceberg" sign. J Clin Ultrasound. 1977; 5: 403-406. Ref.: https://goo.gl/VNEVR2

49. Bronshtein M, Yoffe N, Brandes JM, Blumenfeld Z. Hair as a sonographic marker of ovarian teratomas: improved identifi cation using transvaginal sonography and simulation model. J Clin Ultrasound. 1991; 19: 351-355. Ref.: https://goo.gl/36yfQk

50. Kikkawa F, Nawa A, Tamakoshi K, Ishikava H, Kuzuya K, et al. Diagnosis of squamous cell carcinoma arising from mature cystic teratoma of the ovary. Cancer. 1998; 82: 2249-2255. Ref.: https://goo.gl/6CNZ3A

51. Kawai M, Kano T, Kikkawa F, Morikawa Y, Oguchi H, et al. Seven tumor markers in benign and malignant germ cell tumors of the ovary. Gynecol Oncol. 1992; 45: 248-253. Ref.: https://goo.gl/Fj3BcK

52. Mikuni M, Makinoda S, Tanaka T, Okuda T, Domon $\mathrm{H}$, et al. Evaluation of tumor markers in ovarian dermoid cyst. Acta Obstet Gynaecol Jpn. 1990; 42: 479-484. Ref.: https://goo.gl/F8y11Z

53. Konishi I, Fujii S, Okamura H, Sakahara H, Endo K, et al. Analysis of serum CA125, CEA, AFP, LDH levels and LDH isoenzymes in patients with ovarian tumors-correlation between tumor markers and histological types of ovarian tumors. Acta Obstet Gynaecol Jpn. 1986; 38: 827-836. Ref.: https://goo.gl/hhhYM1

54. Var T, Tonguc EA, Ugur M, Altinbas S, Tokmak A. Tumor markesrs panel and tumor size of ovarian dermoid tumors in reproductive age. Bratisl Lek Listy. 2012; 113: 95-98. Ref.: https://goo.gl/cSrtyE

55. Dede M, Gungor S, Yenen MC, Alanbay I, Duru NK, et al. CA19-9 may have clinical significance in mature cystic teratomas of the ovary. Int J Gynecol Cancer. 2006; 16: 189-193. Ref.: https://goo.gl/Pv6G7E 